\title{
Postmodernizam i grad. Od estetizacije do privatizacije urbanih prostora
}

\author{
Mateo Žanić \\ Institut društvenih znanosti Ivo Pilar - područni centar Vukovar, Hrvatska \\ e-mail:mateo.zanic7@gmail.com
}

\begin{abstract}
SAŽETAK U ovom se radu ispituje na koje su se načine tumačenja postmodernizma bavila pitanjima značajnih promjena u urbanim prostorima. Praćenje tih promjena od šezdesetih godina dvadesetog stoljeća otkriva da su se rasprave oko postmodernizma dominantno vodile unutar triju tematskih područja, a to su arhitektura i izgradnja grada, kapitalističke transformacije grada te reprezentiranje grada. Nakon razmatranja ključnih radova koji su se bavili postmodernom arhitekturom, suvremenim kapitalizmom i teškoćama predstavljanja urbanog prostora, analizira se utjecaj društvenih promjena karakterističnih za postmodernizam na urbane transformacije. Rekonstruiraju se tako estetizacija, privatizacija i fragmentacija grada kao rezultati pojave potrošačkog društva, potrage za novim kolektivnim identifikacijama te pojačanje brige za zadovoljenje osobnih potreba.
\end{abstract}

Ključne riječi: urbani prostor, postmoderna arhitektura, potrošačko društvo, fragmentacija, estetizacija, privatizacija.

\section{Uvod - tumačenja postmodernizma, prostor i društvo}

Pojmovi postmoderne i postmodernizma, kojima se nastojalo označiti novo razdoblje ili, nešto skromnije, skup obilježja koja karakteriziraju nove pojave u kulturi i društvu, izazvali su krajem dvadesetog stoljeća niz polemika (Welch, 1993.; Huyssen, 1999.; Kumar, 2005.). Pojmovnoj zbrci pogodovalo je i to što su osim za detektiranje kulturnih i društvenih promjena ti pojmovi služili za označavanje novih teorijskih pristupa u društvenim i humanističkim znanostima. Široka upotreba pojma dovest ce do toga da se svako predstavljanje postmodernizma suočava s određenim teškoćama, koje proizlaze iz toga što su teorije postmodernosti izrazito eklektične u svojim izvorima te se dosta razilaze u iznošenju ključnih teza (Kumar, 2005.).

U različitim oblicima ti su se pojmovi javljali gotovo od početka dvadesetog stoljeća. Rudolf Pannowitz je tako, slijedeći Nietzscheove ideje, još 1917. godine razmatrao postmodernog čovjeka kao onog koji treba prevladati dekadenciju i nihilizam moderne. Postmodernizam se potom javlja 1934. kod Federica de Onisa pa opet 1947. o njemu piše Arnold Toynbee. Ipak, tek će od rasprava iz šezdesetih godina vođenih 
u Sjedinjenim Američkim Državama oko vrijednosti suvremene književnosti postmoderna zadobiti status „istinskog pojma“ (Welch, 1993.:14). Nakon što je izvorno rabljen u književnosti, pojam se širi te se počinje koristiti i u drugim područjima, kao što su arhitektura, slikarstvo, filozofija, sociologija, geografija i urbanizam. Do kraja se dvadesetog stoljeća tako gotovo u svim znanstvenim područjima javila rasprava o postmoderni i postmodernizmu, premda dakako ne istim intenzitetom i istim žarom. Uzeti zajedno, različiti pristupi kulturi, društvu i filozofiji nastojali su detektirati različite postmoderne trendove koji zapadna društva nakon 60-ih ili 70-ih godina dvadesetog stoljeća čine različitima od istih društava u ranijoj fazi, koju su karakterizirali moderni trendovi. Usprkos tome, različite pristupe povezuje dominantna ideja postmodernizma, a to je odmak od integrirajućih, univerzalističkih principa u društvu i kulturi te usredotočenje na različitost, pa i njeno promicanje (Silverman, 1999.; Naisbitt, 2005.). Variranje ideje različitosti isprepliće se s nizom raznolikih, pa i proturječnih faktora koji govore o tome što postmodernizam jest i što bi trebao biti, zašto je dobar i zašto štetan.

Sve to dolazi do izražaja i u tumačenju prostora u kontekstu postmodernizma. Zanimljivo je napomenuti da se paralelno s raspravama oko postmodernizma počinje isticati „prostorni zaokret“ u društvenim i humanističkim znanostima. Geografi, pa i arhitekti postaju sve češći sudionici teorijskih rasprava o značaju suvremenog doba, dok se istovremeno prostor sve više kao faktor uključuje u analize društvene promjene (Murphet, 2004.; Soja, 2013.).

U ovom je radu stoga cilj razmotriti različite pristupe urbanom prostoru te izdvojiti ključne procese koji su karakteristični za postmodernizam. Pokazat će se pritom da se mapiranju postmodernističkih pristupa može najbolje prići kroz tri područja: artikuliranje postmodernizma u arhitekturi, analize restrukturiranja kapitalizma te epistemološka propitivanja spoznaje prostora. Upravo su se u tim tematskim okvirima u rasprave uključivali neki od vodećih zagovornika ali i kritičara postmodernizma. Nakon toga razmotrit će se društveni procesi koji se vezuju uz postmodernizam te njihove prostorne konzekvence. Kao rezultat društvenih promjena manifestiraju se u urbanim prostorima znakovi estetizacije, privatizacije i fragmentacije. Kroz prikazivanje tih procesa naznačit će se promjene koje oblikuju novu društveno-kulturnu urbanu realnost, koja se odmiče od kontura modernističkog grada.

\section{Rječita arhitektura i oblikovanje prostora}

Raskid s modernošću i modernizmom na različite se načine artikulirao kako u pojedinim umjetnostima tako i u društvenim i humanističkim znanostima. Po opet, prema mnogim zapažanjima, bilo ga je najlakše detektirati u arhitekturi. Wolfgang Welsch, primjerice, tvrdi da je arhitektura posebno pogodna za istraživanje postmodernosti, koja je „za zajedničku svijest, postala najpoznatijom u arhitekturi. Arhitektura je područje artikulacije postmoderne par excellence." (Welsch, 1993.:15). Još jedan značajan tumač postmodernizma Andreas Huyssen pisao je da je u novijoj američkoj arhitekturi istaknut raskid s modernizmom te dodao: „Ništa nije dalje od Van der Roheovih funkcionalističkih staklenih pregradnih zidova od slučajnih 
povijesnih citata koji prevladavaju na mnogim postmodernim fasadama“ (Huyssen, 1999.:208).

Treba, međutim, napomenuti da ni tu, unutar arhitektonske teorije i prakse, postmodernizam nije naišao na opće odobravanje. Osim toga, nije bilo jasno određuje li ga se kao posebno razdoblje ili važan stil koji se pojavio krajem šezdesetih. Međutim, ukupno gledajući u arhitekturi je taj pojam doživio priličan uspjeh jer je uspio „unutar-disciplinarno“ objasniti dio promjena koje su se događale s nastupanjem krize modernizma. On je, dakle, tumačen u kontekstu simptoma, ali i izlaza iz dugačke krize s kojom se susreo moderni pokret. Ta će kriza već šezdesetih rezultirati pisanjem nekoliko značajnih knjiga, kao što su Arbitektura grada Alda Rossija ili Složenost i proturječnost u arhitekturi Roberta Venturija. Osobito će Venturijev rad, kako teorijski tako i projektantski biti, ne bez dobrih razloga, tumačen kao paradigmatski primjer postmodernizma. Dvije će stvari biti kod njega osobito istaknute: reafirmiranje ideje tradicije i povezivanje elitne i masovne kulture (Venturi, 1987.). Ideju tradicije Venturi preuzima od T. S. Eliota, te je ne smatra skupom pravila koja se nasljeđuju od prošlosti, već prije kao trud kojim se kreativno prihvaćaju ali i dopunjavaju neka stara rješenja. Širenje djelokruga onoga što se poima kao kultura i afirmacija tradicije pomažu Venturiju u njegovu osnovnom cilju, afirmaciji složenosti, kaotične živosti, kojom bi se zamijenila dosada jednostavnosti i funkcionalnosti.

Osim toga, u radu pisanom zajedno s Denise Scott Brown i Stevenom Izenourom, R. Venturi ocrtava arhitektonski krajolik Las Vegasa kako bi iznova kritizirao elitizam modernističkog projekta, koji je stalno nastojao mijenjati zatečenu okolinu umjesto da je popravlja. U arhitekturi su, prema njihovom mišljenju, plodna suprotstavljanja uzvišenog i niskog, elitnog i popularnog, zgrade i reklame, koja ne teže za očiglednim jedinstvom (Venturi i sur., 1988.). Shodno tome poruka je za arhitekte da „uklapaju svoje zgrade s obzirom na to kako se gradovi koriste i kako su se koristili, radije nego da ih nastoje redizajnirati prema nekom estetskom metanarativu" (Sim, 2013.:228).

Sedamdesetih godina dvadesetog stoljeća javljaju se radovi u kojima se više ne postavlja samo pitanje što ne valja u modernizmu nego i što poslije modernizma. Ključna će se u tom kontekstu pokazati knjiga Charlesa Jencksa Jezik postmoderne arhitekture, u kojoj se želi jasno izraziti novost u arhitekturi, novost sumirana pod nazivom postmodernizma. Tu se ne radi o odbacivanju modernizma, nego proširenju jezika arhitekture na razne načine, obuhvaćajući vernakularnu arhitekturu, tradiciju, komercijalni žargon ulice. Želi se nadići usredotočenost na univerzalnog čovjeka, koja je modernu dovela do svojevrsnog elitizma. Kao lijek nudi se dvostruko kodiranje kojim arhitektura istovremeno govori eliti i širokoj publici. Premda se više govori o pomaku nego o rezu, on ima izniman značaj za viđenje položaja arhitekture u društvu jer dok je moderna arhitektura pokazivala ambiciju radikalnog mijenjanja ponašanja i društva, za postmodernizam je karakteristično obraćanje pažnje na „reagiranje korisnika“ i stvarna društvena istraživanja. Udaljenom od univerzalnih pretenzija arhitektu ostaje učenje o arhitekturi kao jeziku, uz poučak da su svi jezici zasnovani na naučenim konvencijama, a ne na nečemu što se može neposredno, bez učenja razumjeti. 
Jencksov rad može poslužiti kao primjer nekih obilježja postmodernog teoretiziranja, kao što su nesustavnosti pa i nedosljednosti (Kumar, 2005.). Od 1977. do 2002. godine njegova najpoznatija knjiga obavljena je u osam izdanja, s tim da joj je u posljednjem naslov glasio Nova paradigma u arhitekturi: jezik postmodernizma. Radeći na novim izdanjima knjige Jencks nije samo dodavao analize novih djela autora, kao što su Hans Hollein, James Stirling ili Michael Graves, već je i mijenjao vlastita tumačenja postmoderne arhitekture (Haddad, 2009.). Bez obzira na to, Jencksova lucidna zapažanja, dobro poznavanje povijesti arhitekture te sposobnost da poveže arhitekturu sa širim društvenim i kulturnim procesima učinili su ga jednim od najvažnijih teoretičara i tumača postmodernizma.

Nakon što je postmoderna arhitektura prvotni zamah dobila u Sjedinjenim Američkim Državama, o njoj se sve više počelo raspravljati i u Europi, primjerice u tekstovima Heinricha Klotza i Paola Portoghesija. P. Portoghesi je sudjelovao i u organizaciji poznatog Venecijanskog bijenala iz 1980. godine, koji je bio pozdravljen kao trijumf postmodernizma. Za Portoghesija je jezik postmodernizma značajan jer je u prostor suvremenog grada unio „maštovitost i čovječnost, i u opticaj uveo fragmente i metode velike historijske tradicije Zapada. U svijet arhitekture stupila je nova snaga i nova sloboda, u svijet u kojem je zbog desetljeća stvaralačke stagnacije i nevjerojatne ravnodušnosti nasljeđe modernog pokreta postalo sasvim neefikasno“ (Naisbitt, 2005.: 353).

Ipak, nisu svi bili oduševljeni postmodernom arhitekturom ni venecijanskom izložbom. Možda najpoznatiji kritičar tog događaja bio je Jürgen Habermas. U govoru koji je kasnije objavljen kao tekst naslovljen „Moderna nedovršen projekt“ Habermas postmoderniste predstavlja kao nazadne i neokonzervativne, smatrajući pritom da se pogrešno okreću prošlosti, te da u teoriji vode u krivom smjeru ne razumijevajući dobro odnos sfera znanosti, morala i umjetnosti (Habermas, 2009.). Razmatrajući nešto detaljnije sporove koji su se vodili unutar arhitektonske teorije, Habermas drži da su se javljali brojni i raznoliki protivnici koje je povezivala samo želja da prekinu vezu s arhitekturom moderne (Habermas, 1997.). Posebno izdvaja neohistorizam, postmodernizam te „alternativnu arhitekturu“ kao tri pokreta u kojima se forma i funkcija programski odvajaju te se razlažu veze avangardnog formalnog jezika. Za razliku od kritičara modernog pokreta, Habermas podsjeća na niz važnih stvari koje je on predstavljao i kojima je doprinio, kao što su povezivanje estetike i funkcionalnosti, njegovo potjecanje iz avangardnog duha kao i nastavak zapadnog racionalizma. Činjenica da je nakon Drugog svjetskog rata moderni pokret upao u krizu posljedica je njegova preopterećenja i instrumentaliziranja, te se može smatrati dijelom širih sistemskih problema s kojima se susreće svaki urbanizam.

Rasprave oko postmodernizma nisu ostale na temi projektiranja zgrada, već su se vodile i po pitanju urbanističkih rješenja. Modernizam se tako počeo držati odgovornim za monoton izgled gradova, a njegova zaokupljenost znanošću, tehnikom i utopijskim rješenjima izazivala je sve manje entuzijazma. Određene kritike modernom urbanizmu uputili su već Jane Jacobs i Christopher Alexander, a osobito će važan u tom kontekstu biti rad Colina Rowea i Freda Koettera. Oni su modernom urbanizmu pristupali kroz prizmu opadanja društvene uvjerljivosti jednog utopijskom misijom 
nošenog pokreta. U tom smislu izložili su svoju ideju grada kolaža, u kojem se napušta modernistički sveobuhvatni i ahistorijski odnos prema gradu, a zalaže se za urbanu kompleksnost. Oni primjerice pišu: „bolje je misliti o nagomilavanju malih, čak i proturječnih komada urbanog dekora (nalik proizvodima različitih režima), nego održavati iluzije o totalnim i ‘besprijekornim' rješenjima koje političke okolnosti mogu samo kompromitirati“ (Rowe i Koetter, 2009.:543).

Nakon što je racionalizam modernog pokreta doveden u pitanje, mnogo je više prostora ostavljeno za pitanja značenja prostora i značenja u prostoru, osobito lokalnih značenja bremenitih historijom. Naime, vodeći predstavnici modernog pokreta dominanto su zagovarali apstraktnu arhitekturu, koju ce kasniji teoretičari nazvati „arhitekturom amnezije“ (Jencks, 1997.). Utopijski karakter modernosti temeljio se na ideji racionalnosti, kojom će se naći najbolja prostorna rješenja za ljude gdje god živjeli, a njegovim slabljenjem krenulo se u potragu za lokalnim rješenjima, otvaranjem prema prošlosti. Taj je pomak toliko uočljiv da ga najbolje izražava Svetlana Boym tvrdnjom da je dvadeseto stoljeće započelo futurističkom utopijom koja se bavila budućnošću, a završilo se nostalgijom (Boym, 2005.).

To okretanje prema prošlosti bit će izvor mnogih polemika, pri čemu J. Habermas nije jedini koji je zagovornike postmodernizma optužio za nostalgiju, eklekticizam ili neokonzervativizam. No ono je tumačeno i kao nezadovoljstvo modernošću, odnosno stalnim i sve ubrzanijim modernizacijama društva, prostora i kulture. A. Huyssen tako tvrdi da su modernistički stambeni projekti izgrađeni na temelju standardizacije i racionalizacije postali „simbolima otuđenja i dehumanizacije“ (Huyssen, 1999.:2010). Velik dio postmodernih odgovora na zasićenost univerzalizirajućom racionalnošću težio je otkrivanju lokalnih rješenja, za koje je bilo potrebno znati tradiciju i lokalno pamćenje ${ }^{1}$. Historizacija gradova u kontekstu očuvanja kulturne baštine, spomenika, mjesta sjećanja uočljiv je i dobro dokumentiran proces (Choay, 2001.). Istovremeno, prema mnogima, odnos postmodernosti i prošlosti ostaje dvosmislen, pa i sporan. U postmodernizmu se ne računa na vjernost prošlosti, na njenom ponavljanju i bitnom očuvanju. Prošlosti se dominantno prilazi ironijski te se iz nje nastoje izdvojiti sadržaji kojima se u izvedbi estetski poigrava (Kumar, 2005.; Žanić, 2016.). Stoga se upravo samo pozivanje na prošlost iščitava kao dio simulacijske sklonosti postmoderne zbilje. U tom pravcu ide tumačenje postmodernizma Frederica Jamesona. Premda prema njemu postoje znakovi nostalgije prema prošlosti, težnja da je se ironijski obradi i reprezentira, postmoderno je vrijeme zapravo dominantno zaokupljeno sadašnjošću. Historizacija fragmentiranog prostora biva tako važnim i spornim procesom postmodernizma, koji je gubljenjem utopijskih nada ostao rastrgan između prošlosti i sadašnjosti.

1 Na značaj kulturnog pamćenja u arhitekturi ukazivali su važni autori kao R. Stern i P. Portoghesi. 


\section{Pomaci kapitalizma i upravljanje prostorom}

Priča oko postmodernizma, kada je u pitanju prostor, nije ostala vezana samo uz arhitekturu. Štoviše, izricani su stavovi da je tumačenje arhitektonskih promjena oslanjanjem na samo estetske kategorije „naivno“ (Jameson, 2015.). Stoga je jedan broj znanstvenika nastojao razmotriti što je to što stoji u pozadini prostornih promjena i upravlja njima. Premda postoje bitne razlike među tumačima postmodernizma kao što su Frederic Jameson, Edward W. Soja ili David Harvey, pokazat će se da postoji i poveznica koja ih spaja, a to je pozivanje na kapitalizam.

Osobito poticajni za sva kasnija istraživanja povezanosti društvene dinamike, ekonomskih transformacija i doživljaja postmodernog prostora bili su radovi F. Jamesona. On nizom članaka početkom osamdesetih, od kojih je najpoznatiji „Postmodernizam ili kulturna logika kasnog kapitalizma“, prilazi postmodernizmu kao rezultatu promjena u ekonomskom sistemu kapitalističkog sustava, koje potom utječu na događanja u suvremenoj kulturi. Stilovi u književnosti, filmu ili arhitekturi ne mogu se razmatrati izolirano ili zasebno, već u širem društvenom kontekstu, te stoga i postmodernizam za Jamesona znači „pojam periodizacije čija je funkcija da povezuje pojavu novih formalnih pojava u kulturi sa razvojem nove vrste društvenog života i novog ekonomskog poretka - onoga što se često eufemistički zove modernizacija, postindustrijsko ili potrošačko društvo, društvo medija ili spektakla ili multinacionalni kapitalizam" (Jameson, 2015.:20). Načelno Jameson razlikuje tri faze kapitalizma, koji pritom nalazi izraz u trima tipovima kulture. Realizam je odgovarao fazi tržišnog kapitalizma, a modernizam fazi monopolističkog kapitalizma. Kulturni postmodernizam odgovara onome što Jameson, pozivajući se na rad E. Mandela, zove kasni ili multikorporacijski kapitalizam. Kao konstitutivne značajke postmoderne Jameson navodi novu plitkost kulturnih djela kojima se problematizira sama mogućnost referiranja na stvarni svijet, slabljenje povijesnosti, slabljenje afekata te promjenu odnosa spram nove tehnologije. Krećući u obrazlaganje tog širokog spektra promjena, autor drži da se bitan pomak događa i u teoriji, i to uslijed osporavanja dubinskih modela svojstvenih modernosti, koji se sada nadomještaju koncepcijama prakse, diskursa i tekstualne igre. Slijede analize mutacije postmodernog vremena i prostora. U prvom slučaju javlja se kriza povijesnosti, koja se očituje u stavu da nam povijest ostaje zauvijek nedostupnom, pa je stoga možemo samo tražiti putem „vlastitih pop-predstava i simulacra te povijesti“ (Jameson, 1988.:208). Na primjeru pak Portmanovog hotela Bonaventura Jameson izlaže svoju tezu o postmodernoj mutaciji prostora, po kojoj se u postmodernom hiperprostoru „konačno uspjela transcendirati mogućnost ljudskog tijela da se smjesti, da perceptivno organizira svoju neposrednu okolinu, te da spoznajno ucrta svoju poziciju u planibilnom vanjskom svijetu“ (Jameson, 1988.:222). Postmodernizam koji se tu vidi kao realnost treće ekspanzije kapitalizma, u ovom slučaju preko cijele planete, u onom dijelu koji se tiče prostorne mutacije suočava nas s fragmentiranim i na svoj način nepreglednim prostorom multinacionalnog, globalnog kapitalizma, koji zahtjeva nov način predstavljanja. Upravo iz tih uvida razvit će se neke od najznačajnijih problematiziranja društvene dinamike u globalnom prostoru, prije svega kod autora onoga za što se uvriježio naziv losanđeleska škola urbanizma. Pod tim nazivom predstavlja se rad skupine znanstvenika koji su počevši od osamdesetih godina zastupali tezu da je ono što se događa u Los 
Angelesu i njegovoj široj okolini simptomatično za cjelokupnu sociogeografsku transformaciju koja se odvija u Sjedinjenim Državama (Dear, 2002.; Šarinić i Čaldarović, 2015.). Tako je izvršen preokret, pa je grad koji se prije toga predstavljao kao izuzetak u tumačenju procesa urbanizacije Sjedinjenih Država zauzeo mjesto Chicaga kao svojevrsnog modela za tumačenje urbanih procesa. Među glavne predstavnike losanđeleske škole ubrajaju se Allen Scott, Mike Davis, Michael J. Dear i, vjerojatno najpoznatiji, Edward Soja.

Međutim, treba reći da neki od tih autora prije prihvaćaju osnovni put koji je Jameson naznačio, dakle uvid da promjene u kulturnoj produkciji imaju veze s promjenama u kapitalizmu, ali ne i način argumentacije. Primjerice M. Davis drži da Jameson krivo interpretira Mandelovu knjigu, da povezuje dva različita pristupa kapitalizmu, Wallersteinov i Mandelov, te da previđa da je suvremena kapitalistička akumulacija izraz globalne krize, a ne trijumf poriva kapitalizma za širenjem (Davis, 1985.). Prema samom Davisu postmodernizam se najbolje može odrediti kroz dva aspekta, usponom novog tipa međunarodnih rentijera te odbacivanjem ideala urbane reforme. Ono što iz toga proizlazi fragmentacija je grada te gubljenje kvalitete javnih prostora. Postmoderna arhitektura stoga je prvenstveno uključena u izgradnju suvremenih tvrđava, koje fragmentiraju prostor i usredotočuju se na njegov nadzor.

E. Soja je u opisu svojih postmodernih geografija također krenuo u prikaz niza restrukturiranja koja se nalaze u srži prostornih promjena do kojih dolazi u zadnjoj četvrtini dvadesetog stoljeća. Međutim on veliku pažnju poklanja i važnosti promjena u geografiji, koja je u doba modernosti bila marginalna disciplina kada su u pitanju teorijska dostignuća. Razlog je tome bila dominacija historicizma kao pozicije prema kojoj je vrijeme to koje određuje dinamiku promjena u društvu, pri čemu je prostor potpuno zanemaren. Zalažući se za postmodernu geografiju Soja, dakle, nastoji konceptualizirati, pod utjecajem H. Lefebvrea, M. Foucaulta i J. Bergera, teorijski okvir discipline koja bi trebala ukazati na važnost prostora za razumijevanje društva te tako zauzeti važnije mjesto unutar socijalne teorije. Pravi izazov postmoderne geografije objašnjavanje je postfordističke faze kapitalizma, koji utječe na prostorna restrukturiranja te nalazi svoj izraz u postmodernoj kulturi. Zaključak do kojeg dolazi, fokusiranjem na suvremeni Los Angeles, je taj da se ispod semiotičkog pokrova nalazi „ekonomski poredak, instrumentalna čvorišna struktura, suštinski eksploatatorska podjela rada" (Soja, 2013.:318). Moglo bi se reći da je Soja nastojao dekonstruirati historijski materijalizam kako bi otvorio mjesto za prostorno osjetljiv materijalizam koji bi dao objašnjenje za socioprostorne promjene s kraja dvadesetog stoljeća. Zanimljivo je tako primijetiti da, dok je Habermas označio postmoderniste kao neokonzervativne, Soja postmodernizam čvrsto veže uz marksizam, držeći štoviše da su nemarksisti zapravo antipostmoderni (Minca, 2008.).

Iste godine kada je objavljena Sojina knjiga izašla je i knjiga D. Harveyja „Stanje postmodernosti“ (The Condition of Postmodernity) (Harvey, 1989.). U odnosu na E. Soju D. Harvey se više bavi ekonomskim, pa onda i kulturnim promjenama koje su dovele do postmodernosti. Osim toga, on ne pokazuje nikakvu sklonost prema tom konceptu, već mu je cilj objasniti njegovu pozadinu, dati jasnu sliku uspona postmodernosti. Prema D. Harveyju ne može biti govora o kulturnim transformacijama 
koje bi imale autonomnu logiku promjene, već je područje kulture kao i društvene teorije zahvatila promjena koja svoj uzrok ima u ekonomskim transformacijama, koje se najbolje mogu izraziti promjenom od fordizma k postfordizmu ili fleksibilnoj akumulaciji. Dakle, naglasci na fragmentaciji i raspršivanju koji se mogu detektirati u filozofiji, kulturi, pa i analizama prostora samo reflektiraju promjene do kojih je došlo uslijed promjena režima akumulacije te pojave fleksibilne akumulacije. Tada se znatno povećava brzina kojom se uvode trgovinske, tehnološke i organizacijske inovacije. One utječu na promjenu tipa i dostupnosti proizvoda, tipa radnih odnosa te prostorno vremensku kompresiju.

Tumačenje postmodernizma koje iznosi D. Harvey naslanja se na Jamesonovo, premda se mogu uočiti i neke razlike među njima. F. Jameson kao izvrstan poznavatelj suvremene kulture na mnogim mjestima nijansira svoja tumačenja te bolje ocrtava kulturne trendove, dok se Harvey više bavi ekonomskim promjenama koje pokreću cijeli proces. Obojica su, međutim, velikom pričom nastojala objasniti genezu razdoblja koje je vjerovalo u kraj velikih priča. Ne čudi stoga da je Harveyjeva knjiga naišla na podijeljene reakcije znanstvene zajednice. Mnogi su je, uključujući i Terryja Eagletona, primili s oduševljenjem, no bilo je i kritika od autorica sklonih feminizmu, kao što su Doreen Massey i Rosalyn Deutsche (Woodward i Jones III, 2008.). Nasuprot Harveyju, D. Massey tvrdi da se kod razmatranja postmodernizma trebaju uzeti u obzir pozitivne prakse politika razlika na koje su ukazale feminističke i postkolonijalne studije. R. Deutsche drži da Harvey potpuno zanemaruje dostignuća feminističke teorije te da složene pojave objašnjava jednostavnim uzročnim vezama ne propitujući svoju poziciju s koje kao društveni teoretičar doživljava i tumači zbilju.

Navedeni stavovi pokazuju u kojoj je mjeri tumačenje promjena u urbanim prostorima povezano ne samo s rekonstruiranjem ekonomskih trendova nego i političkim opredjeljenjima. U različitim konfiguracijama kulture, politike i ekonomije formirali su se tako različiti stavovi prema urbanom prostoru, kao i prema suvremenom dobu.

\section{Problemi spoznaje i predstavljanja postmodernog prostora}

Istraživanje grada, pod utjecajem niza društvenih i teorijskih promjena, također je doživjelo značajne pomake te je postalo izrazito zaokupljeno pitanjem reprezentiranja prostora (Dear, 1991., 2002.; Dear i Flusty, 1998.). Među modelima kojima se pristupalo urbanim pitanjima i kojima se predstavljalo grad važnost zadobivaju tekst te osobito slika. Prateći smjenjivanje različitih pristupa gradu u povijesnom presjeku, N. Ellin podsjeća da je od kasnog 19. stoljeća do međuratnog perioda dominirala organska metafora u pristupu gradu. Između ostalih i sociolozi tzv. čikaške škole pristupali su gradu kao organizmu. Od drugog svjetskog rata do šezdesetih godina dominira ideja grada kao stroja, no od kraja 60-ih u arhitekturi, planiranju i sociologiji grad i kultura počinju se promatrati kao nerazmrsivo isprepleteni i podjednako utjecajni. To sve vodi usponu metafore grada kao teksta i kolaža, koju Ellin tumači na sljedeći način: „Promatrajući grad i kulturu kao susretanje značenja više nego funkcija, urbanisti i kulturni antropolozi se okreću materijalnoj kritici u naporu da 
tumače grad i kulturu kao što literarni kritičari tumače tekst [...]. Opsjednutost tekstualnom metaforom za grad i kulturu je otkrivena u obilnom korištenju pojmova kao što su: predavanje, čitljivost, pripovijedanje, svakodnevni, zajednice koje se mogu tumačiti, kao i rastući interes u 'čitanju i pisanju’ arhitekture, grada i kulture" (Ellin, 2004.: 239.).

Treba ipak reći da je isprepletenost postmodernizma i čitanja grada kao teksta povijest koja tek treba biti napisana. No, svakako, nezaobilazno mjesto za taj način tumačenje urbanog prostora pripada Rolandu Barthesu, čiji se rad redovito tematizira u pregledima tekstualnog pristupa prostoru (Stevenson, 2003.). Dakako, Barthes nije prvi koji je raspravljao o toj temi, pa se već i u tekstu „Semiologija i urbanizam“ spominju imena nekih važnih prethodnika za razvijanje navedene problematike, kao što su Victor Hugo i Kevin Lynch. Ipak, tek kod Barthesa imamo jasnu tezu, u kojoj se kaže: „grad je diskurs i ovaj diskurs je u stvari jezik: grad govori svojim stanovnicima, mi govorimo svom gradu, gradu u kome obitavamo; naprosto, naseljavamo ga, prolazimo kroz njega, gledamo u njega" (Barthes, 2009.:424). No, kako se s vremenom mijenjalo Barthesovo poimanje teksta i načina njegove analize, ostala je dvojba na koji način grad čitati kao tekst.

Ono što je simptomatično za širenje tekstualnog modela analize grada ideja je o kulturnoj posredovanosti prostora, koja će se u postmodernizmu radikalizirati i dovesti do pitanja krize reprezentiranja prostora i problema modernističke epistemologije.

Ipak, javljaju se i drugi elementi širenja kulturalističkog pristupa prostoru, u kojima slika zadobiva važnije mjesto od teksta (Featherstone, 2007.). U tom je problematiziranju nesumnjivo važan doprinos Jeana Baudrillarda. On ne samo da se istaknuo kao značajan tumač suvremenih gradova već je uklapajući u svoja pomna promatranja niz neologizama otvorio sasvim nov put tumačenju zbilje. U njegovom pristupu sama zbilja postaje upitna budući da „[n]ovi postmoderni univerzum teži sve pretvoriti u simulakr. To je za Baudrillarda svijet u kojem se sve oko nas očituje u simulacijama, koje su lišene svoje izvanjske realnosti i kopiranog originala. Simulacija apsorbira realnost i ukida svaki kontrast spram realnosti. Više nema realnosti ili 'realnog' koje bi stalo naspram 'imitacije' ili 'mimikrije'. Na djelu su samo stupnjevi pojavljivanja simulacija“ (Kalanj, 2004.:202). Slike koje se gomilaju uslijed konzumerizma i televizijskih izvještaja dovode do destabilizacije realnosti (Featherstone, 2007.). Ono što je za Baudrillarda važno jest da se gube razlike između „istinitog i lažnog“, zbiljskog i imaginarnog, što se očituje u konceptu simulacije. U spoznaji stvarnosti to ima dalekosežne posljedice budući da „[s]imulacija nije više simulacija nekog teritorija, nekog referentnog bića, neke vanjštine. Ona je stvaranje zbilje po modelima bez porijekla i bez stvarnosti: hiperzbilje“ (Baudrillard, 2001.:8). U detektiranju povlaštenih područja pojavljivanja simulacija izdvaja se, uz medicinu, religiju i vojsku, postmoderni prostor. Tako je Disneyland „savršen model svih isprepletenih poredaka simulakruma“ (Baudrillard, 2001.:22). Problem je Disneylanda, međutim, u tome da više ne može funkcionirati kao klasičan model, umanjeni svijet koji predstavlja Ameriku, budući da sama Amerika više nije stvarna, već pripada redu hiperzbilje i simulacije. 
Pristup prostoru kroz prizmu reprezentativnih simbola našao je svoj izraz i u historiji, osobito nakon projekta istraživanja francuskih mjesta sjećanja pod vodstvom Pierrea Nore. Pišući o načinu vođenja tog projekta Nora apostrofira namjeru da se rasvijetli konstrukcija reprezentacija, čijom će se analizom postupno razgraditi neki povijesni predmet. Analizirajući Francusku kao simboličku tvorevinu on pritom ne istražuje prošlost kako se stvarno odigrala, već njezine naknadne upotrebe i zloupotrebe, načine na koji se nešto oblikuje kao tradicija i prenosi na mlađe naraštaje (Nora, 2006.). Norina teza o suvremenoj krizi pamćenja opet se vraća već naznačenoj teškoći na koju upućuje postmodernizam, a to je teškoća pristupu stvarnosti izvan reprezentacija.

Nigdje pitanje spoznaje postmodernog prostora nije eksplicitnije postavljano nego u radovima Michaela J. Deara i Stevena Flustyja. U njihovim radovima nastoji se postići dvostruki cilj. S jedne strane istražiti procese koji suvremeni grad čine drugačijim od modernog grada te s druge strane razviti istraživačke pristupe koji će biti u stanju protumačiti odnose između raznolikih prostora unutar grada kao i načine na koje različite populacije doživljavaju te prostore. Naime, u njihovim se radovima provlači teza da nove društvene promjene zahtijevaju drugačiju senzibilnost te da modernistički pristupi ne mogu dati dovoljno dobre rezultate.

M. Dearu je, dakle, stalo do toga da poveže promjene u postmodernom prostoru s drugačijim epistemološkim pristupom, u kojem bi se otvorio prostor za različite teorijske artikulacije, premda ne bi sve imale jednaku vrijednost. U tom se smislu upušta u prikaz losanđeleske škole urbanizma kao one koja analizira postmoderne procese kao što se čikaška škola nekada bavila modernim gradom. Imperativ prema decentralizaciji, prema Dearu, ključan je faktor u dinamici suvremenih gradova te u novim okolnostima „nije više centar taj koji organizira urbanu okolinu, već okolina određuje što ostaje od centra" (Dear, 2002.:16). Taj autor razmatra različite koncepte koji su se među autorima losanđeleske škole primjenjivali za detektiranje suvremenih trendova, kao što su npr. rubni gradovi, privatopija, kultura heteropolisa, grad kao tematski park, utvrđeni grad, historijska geografija rekonstruiranja, fordistički nasuprot postfordističkom režimu akumulacije te globalizacija. Sve te oznake ne funkcioniraju izdvojeno, nego ih se može umrežavati kako bi dale predodžbu složenog grada u kojem stvari ne funkcioniraju više po principu koncentričnih krugova kakve je predlagao Ernes W. Burgess. Stoga Dear preuzimajući neke od navedenih karakteristika zajedno sa S. Flustyjem skicira mapu postmodernog grada koji je decentriran i sastoji se od niza funkcionalnih kvartova sada konfiguriranih u složenoj mreži.

M. Dear i S. Flusty u naporu da iskažu pozitivne doprinose postmodernizma analiziraju i promjene koje je on unio u geografiju kao znanstvenu disciplinu. Flusty pritom drži da postoje točke oko kojih konvergira rad postmodernih geografa te navodi pet takvih točaka, od kojih se posebno važnom čini ona prema kojoj se značenje više ne drži nečim što je inherentno stvarima, već kao nešto što pojedini društveno i kulturno situirani akteri pripisuju stvarima. Stoga se i sve više istraživanja bavi diskurzivnom proizvodnjom prostora ili načinima na koji se proizvode karte pojedinih prostora. To dovodi do krize klasičnog poimanja istine i njenog zamjenjivanja per- 
spektivno proizvedenim narativima koji su povezani s moći i bore se za društvenu prevlast. U tom smislu: „Repozicionirajući povijesnu istinu kao fragmentarne narative koji se proizvode i nameću u sadašnjosti, postmodernizam potkopava hegelovske ideje prostora kao ostatnog proizvoda idealnog povijesnog vremena i zamjenjuje ih krajolikom diferencijalnih povijesti poredanih u prostoru“ (Flusty, 2008.:225). Nasuprot brojnim prigovorima koji se upućuju postmodernistima Flusty drži da je velika zasluga tog teorijskog preokreta da je utjecao na razvijanje veće senzibilnosti „spram pozicioniranosti drugih" (Flusty, 2008.:227).

M. Dear je pak u svom čitanju Sojinog i Harveyjevog tumačenja postmodernizma uočio ozbiljne nedostatke jer se upravo tu provode „moderni“ prikazi postmodernih geografija. Argumentaciju za tu tvrdnju Dear izvlači iz triju propusta koji su po njemu svojstveni radu prethodno navedenih autora, i to odsutnost bilo kakve dosljedne uključenosti u raspravu o posljedicama „razlika“, nedostatak kritičnog propitivanja vlastitih epistemoloških polazišta te na koncu pogrešno razumijevanje i reprezentiranje postmodernih politika.

U pitanjima spoznaje i reprezentiranja suvremenog urbanog prostora tako se ponavljaju neka pitanja koja su postavile feminističke autorice, a tiču se razumijevanja položaja pojedinih društvenih grupa i njihovih političkih zahtjeva. Kada se isprepletu politička, ekonomska i epistemološka pitanja pojavljuje se složena mreža urbanih procesa. Pitanje koje se pritom nameće je može li se još uvijek izreći suvisla teorija koja bi ih objasnila.

\section{Društveni procesi i postmoderna tumačenja}

Suočavanje s osnovnim uvidima postmodernizma vodi k težnji da se saberu ključne značajke koje su se profilirale u područjima bavljenja urbanim prostorom u razdoblju posljednje četvrtine dvadesetog stoljeća. Kada je u pitanju urbanizam, izdvajanje ključnih točka razlikovanja modernizma i postmodernizma ponuđeno je u knjizi Postmoderni urbanizam (Ellin, 2004.). Nastojanje pak da se iza urbanih promjena razaberu širi društveni procesi vodi do izdvajanja triju važnih društvenih procesa, a to su uspon potrošačkog društva, zaokupljenost kolektivnim identitetima te potraga za osobnim izražavanjem i sigurnošću. Upravo ti procesi pokreću mnoge važne prostorne promjene, u kojima se naknadno reflektiraju, kao što su estetizacija, privatizacija i fragmentacija urbanog prostora.

\subsection{Uspon potrošačkog društva i estetizacija urbanog prostora.}

Teoretičari postmodernizma uvelike su zaokupljeni pitanjem pomaka od društava proizvodnje k društvima potrošnje. U analizama urbanih promjena to se pitanje usko povezuje $s$ istraživanjem važnosti kulture te kulturno posredovanog karaktera stvarnosti (Featherstone, 2007.). Pritom je prvenstveno važno da je kultura prije bila objašnjavana putem drugih čimbenika, dok se sada ozbiljno razmatra „dubinsko“ kulturno kodiranje društvenog. Kultura pritom nije više izdvojena sfera stvarnosti 
koja se iskazuje u knjižnicama i muzejima, već se širi društvom tako da se i politika i ekonomija služe jezikom kulture. Okret k ozbiljnijem shvaćanju kulture vidljiv je u svim trima područjima analize prostora raspravljanima u ovom radu, te dolazi do izražaja na različite načine kod C. Jencksa, F. Jamesona, R. Barthesa i J. Baudrillarda. Kulturni aspekti promjene posebno će doći do izražaja u estetizaciji urbanog procesa kao društvenog i prostornog izraza transformiranja industrijskog grada u grad informacija i imidža koji svoj izraz nalazi u nestajanju granica između elitnog i trivijalnog te u širokoj komodifikaciji urbanog prostora.

Prekoračenje granica između trivijalnog i elitnog nagovješteno je već u Venturijevim radovima, u kojima se pretpostavlja kaotična živost dosadnoj jedinstvenosti (Venturi, 1987.). Ono se razvija i u praćenju postmodernih životnih stilova, koji se povezuju s prolaznim iskustvima i površnim estetskim izrazima (Featherstone, 2007.). Posebno je pritom privlačan koncept hibridnosti, koji sugerira prihvaćanje raznorodnih elementa iz kojih se kreativno izgrađuje novi identitet.

Gradovi krajem dvadesetog stoljeća sređuju se tako da budu što zavodljiviji, specifičniji, turistički privlačniji. Dok se to s jedne strane pozdravlja kao izraz demokratizacije, mogućnosti izražavanja dotada potisnutih populacija (žena, etničkih manjina...) s druge se strane razotkriva kao pobjeda kapitalizma, koji sve pretvara u robu, a od stanovnika grada čini individue zaokupljene sobom i svojim željama. Kako tumačeći Z. Baumana piše M. Singerman: „Estetički prostor postmodernog grada radi na našoj transformaciji iz socijalnih bića s osjećajem za život s drugima u 'nomade' za koje su drugi samo objekti prolaznog pogleda u pokretu (engl. transitory gaze), s kojima onda nemamo vremena uspostaviti odnos“ (Silverman, 1999.:88). Zaoštravanje estetizacije prostora i odnosa prema nižim klasama posebno je došlo do izražaja u procesima gentrifikacije, u kojima je bilo potrebno pražnjenje prostora od dotadašnjih stanovnika kako bi ga se moglo učiniti privlačnim.

Složene odnose između gentrifikacije i pojave novih društvenih skupina nastoji rasvijetliti Mike Featherstone. Pritom taj autor ističe veliku zaslugu F. Jamesona što je tumačio postmodernizam kao važnu kulturnu transformaciju i nastojao ga pritom povezati sa širim povijesnim procesima (Featherstone, 2007.). Međutim, problem je što pritom analiza ide od ekonomije do kulture, a zaobilaze se društveni akteri i pitanje društvenih odnosa. Razvijajući svojevrsnu sociologiju postmodernizma Featherstone, pod znatnim utjecajem P. Bourdieua, razmatra kako različite društvene grupe ulaze u društvene sukobe zbog svojih različitih shvaćanja kulture te kako dolazi do pojave nove srednje klase, novih kulturnih posrednika, koji rade na širenju drugačijih simboličkih dobara i usluga. Ti procesi nalaze svoje izraze u gradovima, pri čemu se Featherstone poziva na proces postmodernizacije korišten prethodno od Sharon Zukin i Philipa Cookea. Taj proces događa se usporedno s deindustrijalizacijom centara gradova koji se gentrificiraju, pri čemu važnu ulogu imaju pripadnici nove srednje klase koji te prostore sređuju kako bi bili konkurentna turistička mjesta i mjesta potrošnje. Postmodernizam se tako može povezati kako s akterima koji ga promiču tako i s društvenim manifestacijama. Estetizacija života povezana je s promocijom životnih stilova koji su obilježeni aktivnom stilizacijom života, pri čemu je istraživanje prolaznih iskustava postalo važnije od potrage za koherentno- 
šću (Feathertone, 2007.). Pripadnici nove srednje klase potiču skup promjena koji obuhvaća težnju za izražavanjem, izgledom, opčinjenost identitetom. Rezultat su toga umjetnički projekti koji podižu kulturni kapital gradova, odnosno popravljaju imidž gradova koji su u stalnom kulturnom natjecanju.

Urbani postmoderni prostor nastoji se tako učiniti atraktivnim i zabavnim ili, drugačije rečeno, zavodljivim. Tako se odgovara na promjene u društvenoj strukturi i potrošnji, koje se očituju u usponu tercijarnog sektora te usponu turizma kao važne privredne grane. Prostori se tako estetiziraju iz različitih razloga, da bi se učinili atraktivnima, da bi se posjetili, brendirali i prodali.

\subsection{Politike identiteta i fragmentacija urbanog prostora}

Za problematiziranje odnosa cjelina - pluralitet može se konstatirati da tvori jedno od ključnih filozofskih i socioloških pomaka između moderne i postmoderne. Jednostavno rečeno, autori koji se bave detektiranjem postmodernog stanja ukazuju na raspad cjeline ili jedinstva bilo da govore o krizi metanarativa ili da se služe nekim drugim terminološkim alatom. Međutim, mnogi tumači postmodernizma bili su svjesni problema da pluralizam koji su pozdravljali lako može odvesti u eklekticizam i proizvoljnost. W. Welsh je tako pisao da je postmoderni kriterij višejezičnosti ispunjen samo ako pojedinačni vokabulari „ne bruje uokolo kao jezičke krpe, nego da se predoče logika i specifične mogućnosti njihova jezika" (Welsh, 1993.:19). Na sličan će način pisati M. Dear, koji će se u geografiji zalagati za postmoderni pluralitet pozicija, ali istovremeno odbijati ono što vidi kao obilježje dekonstrukcije, a to je pozicija „sve je dozvoljeno" (engl. anything goes). Za postmoderni pluralitet zalagat će se i C. Jencks, koji hvali ono što naziva heteroarhitektura, koja obilježava Los Angeles. O njoj Jencks piše: „glavni smisao heteroarhitekture prihvaćanje je različitih glasova koji kreiraju grad, ne potiskivanje ni jednog od njih, te stvaranje iz njihova dijaloga jednog oblika šireg dijaloga" (Dear i Flusty, 1998.:56). U heteropolisu arhitektura mora izraziti kulturu različitih etničkih grupa koje nastanjuju grad (Jencks, 1997.). U tom smislu arhitektura postaje element izgradnje kolektivnih identiteta, koji su povezani s historizacijom gradskih prostora i širenjem osjetljivosti na značenja koja se iz njih mogu iščitati.

Premda je odnos zagovornika multikulturalizma te različitih društvenih pokreta, kao što je feministički, prema postmodernizmu krajnje složen, pokazuje se da su osnovni poticaji postmodernizma, kao naglašavanje dezintegracije modernog poretka, poticanje pluralnosti, kulturalizacije politike te opće kontekstualizacije, učinili da se i sami ti pokreti često dovode u blisku vezu s postmodernizmom (Bertens, 1995.). Ne čudi stoga da se i u urbanim studijima počinje sve ozbiljnije razmatrati pitanje zaštite kultura različitih društvenih skupina. Leonie Sandercock je tako razvila pristup prema kojem postmoderni urbani projekti moraju biti osjetljivi prema kulturnim razlikama, zbog čega se projektanti moraju više oslanjati na kontekstualno i iskustveno znanje nego na znanstvene analize (Taylor, 2011.). Prema L. Sandercock modernističko je planiranje pretpostavljalo državu kao autoritet i nositelja projekata kojima se trebao postići opći javni interes. Postmoderno planiranje treba napustiti 
pristup koji ide od vrha prema dolje (engl. top-down) te se nasuprot tome koncentrirati na različite društvene i etničke zajednice, koje imaju svoje različite interese i kulture. Stoga planiranje u takvim „multikulturnim područjima zahtijeva novi oblik multikulturne pismenosti“ (Taylor, 2011.:395). Postmoderni se prostor odmiče od racionalnih nacrta koji su s utopijskim ciljevima nastojali stalno stvarati nešto novo, ne vodeći računa o lokalnim kontekstima. Sada se nastoji voditi računa o regiji, etničkoj skupini, historiji, koji zadobivaju važnu ulogu u razumijevanju prostora, njegovom očuvanju i izgradnji.

Međutim, pluralizam je i predmet kritike pojedinih analitičara koji postmodernizmu prilaze iz perspektive restrukturiranja suvremenog kapitalističkog sistema ili urušavanja poretka modernog grada. Autorice i autori kao što su, primjerice, Françoise Choay, Paul Virilio ili Marc Auge dijele mišljenje da nestajanje kompleksnog i slojevitog jezika modernog grada znači i gubitak „živog“ osjećaja za mjesto te uspostavu na njegovo mjesto poretka koji se temelji na reprezentacijama ili simulacijama stvarnosti (Silverman, 1999.). M. Davis, koji piše radije o polarizaciji nego o fragmentaciji prostora, drži da dolazi do pojave radikalno antagoniziranih prostora, koji su posljedica povećanja rasnih i klasnih razlika u američkim gradovima. Dolazi pritom do pojave urbanih utvrda, putem kojih elite nastoje osigurati svoju sigurnost u nesigurnom okružju postmodernog grada. Odmak od centralizacije i funkcionalizacije, koji su se zagovarali u razdoblju realizacije velikih modernističkih projekata, ima tako niz posljedica kako u izgledu tako i u živoj stvarnosti grada s kraja dvadesetog stoljeća.

\subsection{Zaokupljenost osobnim i urušavanje javne sfere}

Porast važnosti privatnog te opadanje važnosti javnog o kojem se raspravlja u postmodernosti nalazi svoj izraz u dvama važnim procesima, širenju privatnih prostora te trendu zaokupljenosti privatnošću u svakodnevnom životu. Julian Murphet navodi da je urbani postmodernizam posljedica neuspjeha koji je 1960-ih doživio kasnomoderni koncept birokratskog gradskog planiranja, u kojem su ključnu ulogu igrale države. Dolazi tada do opadanja državnih investicija u urbanu obnovu te se u oblikovanje gradova u većoj mjeri uključuje međunarodni kapital. To vodi k oblikovanju prostora u skladu s ciljevima proširenja trgovine, odnosno potrošnje. Prostor istovremeno biva sve više estetiziran ali i nadziran, odnosno kontroliran. U tom kontekstu „privatizacija javnog prostora od internacionalnog kapitala znači eroziju i, prema nekim kritičarima, čak potpuno nestajanje onoga što se zvalo 'civilno društvo’ ili javna sfera“ (Murphet, 2004.:123). Restrukturiranje Los Angelesa prema M. Davisu vodilo je prema projektima obnove centra koji su imali za cilj eliminiranje javnih prostora kao što su pločnici i parkovi. To je posljedica isticanja sigurnosti kao ključnog kriterija koji se mora zadovoljiti u izgradnji grada (Davis, 2011.).

Na krizu javnog prostora u suvremenim gradovima, uzrokovanu porastom nesigurnosti i jačanjem straha, ukazuje i Zygmunt Bauman. Povlačenje s javnih mjesta za njega znači da nestaje i vještina dijaloga i pregovaranja koja bi trebala omogućiti život s drugačijim i različitim. Naime, za Baumana su sami javni prostori „mjesta susreta stranaca, tako da predstavljaju kondenzaciju i ekstrakt glavnih karakteristika 
urbanog života. Upravo na javnim mjestima urbani život, sa svim što ga odvaja od drugih vidova ljudskog zajedništva, postiže svoj najpotpuniji izraz, zajedno sa svojim najkarakterističnijim radostima i tugama, slutnjama i nadama“ (Bauman, 2009.:95). $\mathrm{Na}$ javnim smo mjestima izloženi rizicima, no istovremeno upravo se tu događaju i avanture, iznenađenja i glavne atrakcije života u gradu. Ipak, Bauman drži da javna mjesta mogu ispuniti svoje ključne urbane funkcije tek ukoliko se odreknu modernističke ambicije da poravnavaju sve razlike kao i postmodernističkog stava koji teži učvršćivanju razlika. Dakle, na javnim bi mjestima trebale biti dozvoljene i prepoznate različitosti, ali i potaknut dijalog među njima.

Isticanje sigurnosti kao vrijednosti koju treba osigurati grad dolazi do izražaja i u nekim konceptima koje M. Dear drži korisnim za razmišljanje o postmodernom urbanizmu, kao što su privatopije i utvrđeni gradovi. Privatopije su tako ograđena naselja nastala zajedničkim ulaganjem stanara u kojima se gubi ideja građanstva shvaćena kao ostvarenje zajedničkog pripadanja gradu (Dear, 2002.; Šarinić i Čaldarović, 2015.). Uslijed nesigurnosti urbanog okružja pojedinci se okreću privatnom prostoru te u njemu organiziraju svakodnevni život, a unaprjeđenje uvjeta privatnog života postaje njihov urbani san.

Promjene u prostoru povezane su i s promjenom u odnosu ljudi prema stvarnosti, kojom dominiraju nove tehnologije i nove društvene vrijednosti. M. Pawley, primjerice, piše: „Trijumf potrošačkog društva je trijumf svih privatnih nad javnim ciljevima“ (Ellin, 2004.:122). G. Lipovetsky također piše o kraju javne sfere koja je bila karakteristična za tradicionalni grad. Ona se gubi zbog uspona privatizacije individualnih potreba i želja koje su karakteristične za postmodernost (Silverman, 1999.:76). Zaokupljenost vlastitom biografijom vodi tako atomizaciji društva, pri čemu na mjesto javne sfere stupa mnoštvo privremenih mreža u kojima se pojedinci povezuju kako bi ostvarili svoje privatne interese. Pokazuje se tako da je osim orijentacije prema jačanju partikularnih grupnih identiteta, što promiče multikulturalizam, i jačanje individualizma nagrizlo modernistički projekt, koji je kroz realiziranje univerzalističkih standarda obećavao ostvariti funkcionalno urbano društvo.

\section{Zaključak}

F. Jameson se više puta vraćao tvrdnji prema kojoj je „shvaćanje sadašnjosti iznutra najproblematičniji zadatak s kojim se um može suočiti“ (Jameson, 2015.:50). U tom kontekstu treba vrednovati i značaj postmodernizma kao nastojanja da se neposredno, na širi, premda i paradoksalniji način, tumači stvarnost kraja dvadesetog stoljeća. Postmodernizam će se pritom dovoditi u vezu s nizom različitih pojava i teorija koje su se javile u tom razdoblju. Povezivan je tako s postindustrijskim društvom, fleksibilnom akumulacijom, multikulturalizmom i jačanjem individualizma. Pritom se pojmovi postmodernizma i postmodernosti uvijek tumače relacijski, podrazumijevajući određeni pomak u odnosu na modernost i modernizam. Sve te teme našle su svoje mjesto i u raspravama koje su se bavile postmodernim transformacijama urbanih prostora. Prema postmodernim tumačenjima moderne se karakteristike gradova mijenjaju, pa tako težnju za cjelovitošću zamjenjuje fragmentacija, grad masovne 
proizvodnje postaje estetizirani grad potrošnje, a dodatno jačanje individualizma vodi daljnjem urušavanju javne sfere. U tim procesima do punog izražaja dolazi isprepletenost društvenih i kulturnih procesa. Naime, prema postmodernim tumačenjima moderni okviri identifikacije kao što su klasa, nacija i obitelj prolaze kroz manje ili veće krize, što utječe na uspon različitih zamišljenih identitetskih zajednica ili rastuću individualizaciju, koja utječe na zahtjeve za privatizacijom prostora. Širenjem potrošačkog društva raste vrijednost uljepšavanja gradova, koji postaju predmetom različitih tipova reprezentiranja koji im pomažu u stvaranju prepoznatljivog imidža. Zanimljivo je, međutim, da uslijed dojma ubrzanja vremena i gradska prošlost dobiva na važnosti, tako da ponekad čak i negativne epizode gradske prošlosti, kao primjerice u Berlinu, bivaju muzealizirane i izložene.

Početkom dvadeset i prvog stoljeća ideja postmodernizma polako gubi na snazi, a mnogi značajni tumači, kao što su Z. Bauman i F. Jameson, nalaze nove koncepte za tumačenje suvremene zbilje. Međutim, premda je rasprava oko postmodernizma jenjala, procesi koji su se detektirali kao ključni u tumačenju postmodernih urbanih promjena ne prestaju biti važni. Bilo da ih se zahvaća kao izraz kulturno-epistemološkog pomaka, djelovanja tržišnih sila kojima upravlja kapitalizam ili društvenih procesa koji utječu na promjene u procesima oblikovanja kolektivnih identifikacija, procesi fragmentacije, privatizacije i estetizacije i dalje su iznimno korisni pojmovi za koncipiranje grada od urbane sociologije do kulturne geografije. Napokon, ključna pitanja postavljena u „razdoblju postmodernizama“ i dalje ostaju otvorena i poticajna, kao primjerice pitanje kako se isprepleću i razilaze procesi širenja popularne kulture, političke demokratizacije i ekonomskog porobljavanja.

\section{Literatura}

1. Barthes, R. (2009). Semiologija i urbanizam, u: Perović, M. (Ur.). Teorija arhitekture XX veka: antologija. Beograd: Građevinska knjiga.

2. Baudrillard, J. (2001). Simulakrumi i simulacija. Karlovac: Naklada Društva arhitekata, građevinara i geodeta.

3. Bauman, Z. (2009). Fluidni život. Novi Sad: Mediterran Publishing.

4. Bertens, H. (1995). The Idea of Postmodern. London and New York: Routledge.

5. Boym, S. (2005). Budućnost nostalgije. Beograd: Geopoetika.

6. Choay, F. (2001). The Invention of Historic Monument. Cambridge: Cambridge University Press.

7. Crook, S. (2001). Social Theory and the Postmodern, in: Ritzer, G. and Smart, B. (Eds.). Handbook of Social Theory. London: SAGE Publications.

8. Davis, M. (1985). Urban Renaissance and the Spirit of Postmodernism. New Left Review, 151: 106-113.

9. Davis, M. (2011). Fortress L.A., in: LeGates Richard, T. and Stout, F. (ur.) The City Reader. London and New York: Routledge

10. Dear, M. (1991). The Premature Demise of Postmodern Urbanism. Cultural Anthropology, 6 (4): 538-552.

11. Dear, M. (2002). Los Angeles and the Chicago School: Invitation to a Debate, City \& Community, 1 (1): 5-32. 
12. Dear, M. and Flusty, S. (1998). Postmodern Urbanism. Annales of the Association of American Geographers, 88 (1): 50-72.

13. Ellin, N. (2004). Postmoderni urbanizam. Beograd: Orion Art.

14. Featherstone, M. (2007). Consumer Culture and Postmodernism. SAGE Publications.

15. Flusty, S. (2008). Postmodernizam, u: Atkinson, D.; Jackson, P.; Sibley, D.; Washborune, N. (Ur.). Kulturna geografija. Kritički rječnik ključnih pojmova. Zagreb: Disput.

16. Habermas, J. (1997). Modern and Postmodern Architecture, in: Leach, N. (Ed.). Rethinking Architecture. London and New York: Routledge.

17. Habermas, J. (2009). Moderna - nedovršen projekt. Politička misao, 46 (2): 96111.

18. Harvey, D. (1989). The Condition of Postmodernity: An Enquiry into the Origins of Cultural Change. Oxford and Cambridge: Ma: Blackwell.

19. Haddad, E. (2009). Charles Jencks and the Historiography of Post-Modernism. The Journal of Architecture, 14 (4): 493-510.

20. Huyssen, A. (1999). Zemljovid postmodernoga, u: Nicholson, L. (Ur.). Feminizam/Postmodernizam. Zagreb: Liberta - Centar za ženske studije.

21. Jameson, F. (1988). Postmodernizam ili kulturna logika kasnog kapitalizma, u: Kuvačić, I. i Flego, G. (Ur.). Postmoderna. Nove epoha ili zabluda. Zagreb: Naprijed.

22. Jameson, F. (2015). Kraj umetnosti ili kraj istorije. Beograd: Art press.

23. Jencks, C. (1985). Jezik postmoderne arhitekture. Beograd: Građevinska knjiga.

24. Jencks, C. (1997). Post-modern Architecture and Time Fusion, in: Bertens H. and Fokkema, D. (Eds.). International Postmodernism: Theory and Literary Practice. Amsterdam/Philadelphia: John Benjamins Publishing Company.

25. Kalanj, R. (2004). Globalizacija i postmodernost. Zagreb: Politička kultura.

26. Kumar, K. (2005). From Post-Industrial to Post-Modern Society. New Theories of the Contemporary World. Blackwell Publishing.

27. Minca, C. (2008). Postmodern geographies (1989): Edward Soja, in: Hubbard P.; Kitichin, R. and Valentine, G. (Eds.). Key Texts in Human Geography. LondonSAGE Publications.

28. Murphet, J. (2004). Postmodernism and Space, in: Connor, S. (Ed.). The Cambridge Companion to Postmodernism. Cambridge: Cambridge University Press.

29. Nesbitt, K. (2005). Teorija arhitekture postmodernizma, u: Perović, M. (Ur.). Historija moderne arhitekture: antologija tekstova. Knjiga 3. Beograd: Arhitektonski fakultet.

30. Nora, P. (2006). Između Pamćenja i Historije. Problematika mjesta, u: Brkljačić, M. i Prlenda, S. (Ur). Kultura pamćenja i historija. Zagreb: Golden marketing Tehnička knjiga.

31. Rowe, C. i Koetter, F. (2009). Grad kolaž (odlomci), u: Perović, M. (Ur.). Teorija arbitekture XX veka: antologija. Beograd: Građevinska knjiga.

32. Silverman, M. (1999). Facing Postmodernity. Contemporary French thought on culture and society. London - New York: Routledge.

33. Sim, S. (2013). Fifty Key Postmodern Thinkers. London and New York: Routledge.

34. Stevenson, D. (2003). Cities and Urban Cultures. Maidenhead/Philadelphia: Open University Press. 
35. Soja, E. (2013). Postmoderne geografije. Beograd: Centar za medije i komunikacije - Fakultet za medije i komunikacije.

36. Šarinić, J. i Čaldarović, O. (2015). Suvremena sociologija grada. Zagreb: Naklada Jesenski i Turk - Hrvatsko sociološko društvo.

37. Taylor, N. (2011). Anglo American Town Planning Theory Since 1945: Three Significant Developments But no Paradigm Shifts, in: LeGates, R. T. and Stout, F. (Eds.). The City Reader. London and New York: Routledge.

38. Venturi, R. (1987). Složenosti i protivrečnosti u arbitekturi. Beograd: Građevinska knjiga.

39. Venturi, R.; Scott Brown, D. and Izenour, S. (1988). Learning from Las Vegas. Cambridge: MIT Press.

40. Welsch, W. (1993). Postmoderna. Genealogija i značenje jednog spornog pojma, u: Kemper Peter (Ur.). Postmoderna ili borba za budućnost. Zagreb: August Cesarec.

41. Woodward, K. and Jones III, J. P. (2008). The Condition of Postmodernity (1989): David Harvey, in: Hubbard, P.; Kitichin, R. and Valentine, G. (Eds.). Key Texts in Human Geography. London: SAGE Publications.

42. Žanić, M. (2015). Kultura pamćenja i prostor grada. Prilog arhitektonskim i urbanističkim tumačenjima od Ruskina do postmodernizma. Socijalna ekologija, 24 (2-3): 173-190. 
Pregledni rad

Mateo Žanić

Institute of Social Sciences Ivo Pilar - Centre Vukovar, Croatia

e-mail:mateo.zanic7@gmail.com

\title{
Postmodernism and City. From Aestheticization to Privatization of Urban Spaces
}

\begin{abstract}
The paper examines the ways interpretations of postmodernism dealt with questions of significant changes in urban space. Investigation of those changes from the 1960 s reveals that the discussions about postmodernism mostly involved three thematic areas, namely the architecture and construction of the city, the capitalist transformation of the city, and representations of the city. After reviewing key papers dealing with postmodern architecture, modern capitalism, and difficulties in representing urban space, the impact of social changes characteristic of postmodernism on urban transformations is analyzed. Aestheticization, privatization, and fragmentation appearing in the consumer society, the search for new collective identifications, and an increased concern about satisfying personal needs are reconstructed in that context.
\end{abstract}

Key words: urban space, postmodern architecture, consumerist society, fragmentation, aestheticization, privatization. 